\title{
National Economical Integration and Urban Planning: Case Study Albania
}

\author{
Msc. Arch. Otjela Lubonja \\ PhD Candidate, Head of departament of Architecture \\ Vitrina University, Tirana, Albania \\ Tel: +355 693223549, Email: otjela@yahoo.com
}

\section{Doi:10.5901/ajis.2013.v2n9p622}

\section{Abstract}

Albania, by the end of the last century, was a very isolated country with a centralised economy, small towns, many villages and everything under the totalitarian system. Later on, during the two last decades, the country has experienced many changes. The first one together with the political change from the 'monopartitism' to the pluralism system, was the change of the economy, from being centralised into the market-based one. The other big change was the internal migration, people moved from villages to towns. Those changes have both positive and negative sides, which indicated in the ballance of the urbanization of a country and in the economy, as well. Recent theories of urbanization have emphasized that it is not an autonomous process, but must be analyzed with the main patterns of political and economical changes. Internal migration, connected with the new landscape of urbanization was developed through three stages since the fall of communism:

- $\quad$ The first phase was dominated by the informal sector.

- $\quad$ The second phase was characterized by consolidation and the emergence of the informal sector to the formal sector.

- $\quad$ The third and current phase consists in strengthening the formal sector and informal regulation of development. The main objective of the third phase will be to formalize and integrate the real estate market.

It is visible the transformation from informal to formal sector and such a development would affect areas of the financial system of a country. Clearly the restructuring reforms have generated economic growth. Financial sustainability is a developed system, which supports and promotes economical development and, a developed economy is connected with the stable financial sector. There is still significant room for improvement in the management of urban planning development, in particular to find a more appropriate public and private interests in land development and the use of both, private and public, property. The questions are connected with the sectors that affect the economical development of a country:

- First, mention construction

- The trade sector

- Infrastructure

- Tourism

The analyses of the above topics are connected with National Economical Integration and Urban Planning.

Keywords: economical integration, urban planning, centralised economy and market- based economy, formal and informal sector, sustainable development, financial sustainability,

\section{Introduction}

The urbanisation during the 20th century is a global process in which the third world is mostly enticed. Before the 1900s all the growth of the cities was almost towards the west, and the Third World was enlarged during the nex fifty years. The population of the cities in general is growing faster compared to the entire world population in the $1975,39 \%$ of the population lived in the urban areas, this figure is forcasted to be $50 \%$ in 2000 and $65 \%$ for the $2025^{1}$

Ther latest theories in the urbanisaton have emphasised that it is not an atonom process, but it should be analysed with the main/principal models of the political and economical changes.

Our nation, Albania, since about 20 years, was known to be an isolated society, a place which has surpassed many changes in a short period of time. The city was too small compared to the modern standarts. We will see a transition from a solid economy to a market based economy. In the recent years it is recognised an economic increase and an increase of the population as well. This kind of rapid change has its positive and negative sides which is taken in consideration in the urbanisation of a place. 


\section{Development}

The urbanization, emphasised Harvey, is an aspect of the environment created and caused from the spread of the industrial capitalism. ${ }^{1}$

How is this urbanisation transmited in Albania?

Urbanisation in Albania has passed through three different phases since the fall of communism:

- First phase was dominated by the informal sector.

- Second phase was charecterised from the consolidation of the informal sector and the introduction of the formal sector.

- Third Phase or the current consists in the strengthening of the formal sector and the regulation of the informal developments. The main objective during the third phase would be the legalisation and the integration of the real estate market .

The first phase of the urbanisation, between 1991 and the 1997, was dominated by an internal masive migration from the northen and eastern areas and people from the remote areas of the western and the coastal remote areas.

During the beginings of the transition, the Albanian population was $75 \%$ contrymen- a high persentage for a countrymen popullation of the XX century. The socialist regime had agressively pressed the needs for shelter. Until 1991, the rented appartments as a states property were the $70 \%$ of the urben offer for sheltering. The use/consume of the habitat area was nearly $5 \mathrm{~m} 2$ per person in the urban areas (compared with, for instance $16 \mathrm{~m} 2$ per person during the transition period in Bulgaria). ${ }^{2}$

This phase was helpful as it contributed in the sub-division of the land, in small parcels. During the second phase, the formal sector started to operate mainly in the center of the cities by redeveloping the land occupied from the old buildings. The majority of the buidings constructed by the formal sector were multi store apartments or bussiness headquarters and offices. Consecuently, the informal sector continues with the increase of reservation for houses in the form of the detached houses in the suburbs.

In the periurban areas the main concern of the inhabitants is the absence of the regular supply with water, sanitation, electric power, or public transport, and the distance from school and health service centers.

Albanian cities now are in the third phase of the urbanisation, during which the laws and the regulations should be developed and applied so that all real estate - existing or under construction reserve - will be totally formal.

Fig 1. A simple sample of comparison is given in the following picture:

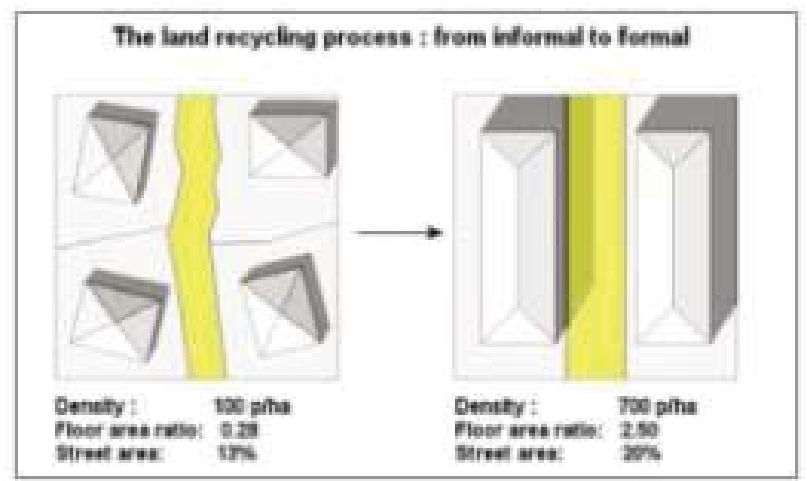

Picture $\mathrm{nr} 1$ gives a scematic introduction of the transformation of an informal area with a low density to a formal area with a higher denstity.

\footnotetext{
${ }^{1}$ Anthony Giddens "sociologjia" faqe 531

${ }^{2}$ Evaluation of the urban sector in Albania
} 
Harvey explains that in the modern urbanisation usually the space is restructured3, we recognise that this is clearly made evident in our country, the owners of the private houses in the informal areas are established in appartments and they are compensated for their house and their land.

In many other places, the constructers recycle the land by buying formal properties and constructing them.

What is unique for Albania, is the transformation from the informal into the formal, such a development of the areas would indicate in the financial system of a country. It is evident that the reforms of the reconstucting reforms have generated economical growth.

The financial stability is a developed system, it supports and encourages the economic development, also a development economy can do nothing without a developed finnancial sector. It needs a stable financial sector, which will resist the negative and cyclical developments and external shocks.

Yet, there is enough room for improvement in the management of the urban development, particularly in finding the appropriate solutions for the public and private interests in the development of the land and the usage of the property.

The urban increase will continue, but in smaller amounts, this related with the increase of the norm of the urbanisation in similiar levels in the other European countries

Albania is the only place in Europe which has a norm of the natural increase over 1 percent during the years of (King dhe Vullnetari, 2003; INSTAT, 2002). Furthermore between the years 1989 - 2001, Albania has had a decrease of 3.6 percent in the number of population.

In the 2001, around 600,000 to 700,000 , or a fifth of the native population in Albania, is estimated to live abroad, mainly in Greece and Italy. (Carletto et al, 2004).

International migration continued to grow, largely as a result of low wages and wealth differences between Albania and neighbor countries, the public sector, inadequate infrastructure and service provision. Since 2001 the economy has improved steadily.

Fig 2. The absolut number of the population in the city and the \% of the number of the population on district bases , 19892001

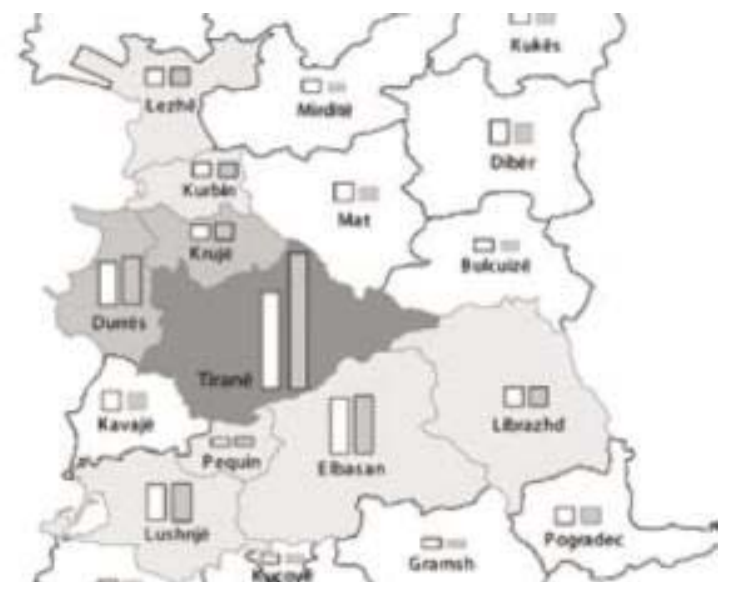

Source: Datas by INSTAT

We see, picture $\mathrm{nr} 2$ and we recognise the central regions and the coastline became the most favourite destination for the internal migration. Between the years 1989 dhe 2001, Tirana and Durrës were at the top of the list of the populated regions which welcomed migrants, absorbed aproximately three quarters of the general influxes of the internal migration.

Fig 3. The central- coastal region is the main position preffered by the migrants 


\begin{tabular}{|l|c|c|c|c|}
\hline \multicolumn{5}{|c|}{ Shpërndarjet e migracionit ndër-rajonal(1989-2001), numri i personave dhe shpërndarjes në përqindje } \\
\hline \multirow{2}{*}{ Rajoni i prejardhjes } & \multicolumn{4}{|c|}{ Rajoni i vendosjes } \\
\cline { 2 - 5 } & Veri-Lindje & Qëndror-Bregdetar & Jug-Lindje & Totali \\
\hline Veri-Lindje & & 107,433 & 1,465 & 108,898 \\
\hline Në \% & & 98.7 & 1.3 & 100 \\
\hline Qëndror/Bregdetar & 2,491 & & 11,721 & 14,212 \\
\hline Nē \% & 17.5 & & 82.5 & 100.00 \\
\hline Jug-Lindje & 1,273 & 58,256 & & 59,529 \\
\hline Në \% & 2.1 & 97.9 & & 100 \\
\hline Totali & 3,764 & 165,689 & 13,186 & 182,639 \\
\hline
\end{tabular}

Burimi: INSTAT Regjistrimi i përgjithshëm i popullsisë 2001.

The increase of the urban population is concentrated. According to the registration of the population with 43 percent , from 238,057 inhabitants in 1989 to 343,078 in the 2001.

Fig 4. The urban population could continue growing in the next decade

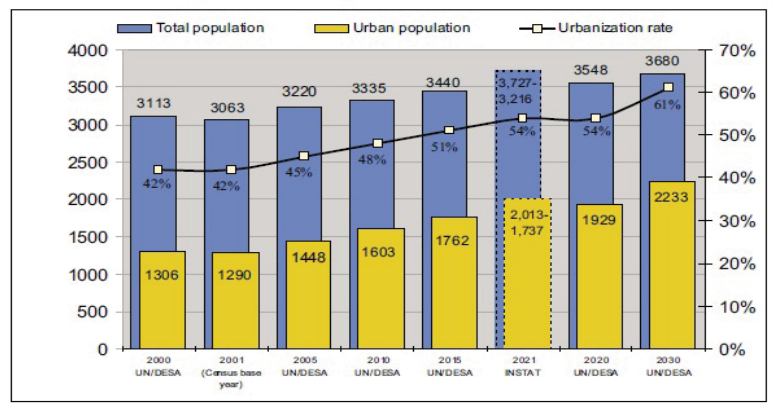

Source: INSTAT (2004), KB (2004).

The natural growth of the urban population will dominate in the demographic growth, such as the cities which welcome most of the new inhabitants.

The Question is that where in the urban system we will have the new growth of the city?

According to INSTAT (2004), the population in the districts of Tiranë and Durrës, in the next twenty years , will grow from 700,000 to $1,200,000$.

This growth of 70 percent is due to the continuous establishment of the migrants who come from the other parts of the country, this combined with the natural growth of the existing population in the region. It is expected the continuous preponderance of the metropolitan zone Tirane-Durres in the system of the city. This should be seen how it indicates in the economic development of a country.

The question is which are the sectors which have an impact in the economic development of a country?

Firstly, we mention that the construction sector of the capital is rapidly developing and it is estimated to take into account up to 25 percent of the metropolitan employement.

The industry is dominated from big firms of the formal sector which construst middle size blocks with appartments of high prices in the city centre, and informal constructors which help in further addings of the detached houses in the urban slums.

Trade sector is growing with a sustainability, and with an importance in the retail sector.

Considering the limited choices for employment and relatively the low costs for starting a business, it is estimated that the commerce constitutes on more than half of all the businesses and a third of employment in Tirana capital.

The infrastructure - is very important for the development of torurism, it increases the efficiency of the private productivity and the distribution of the services of tourism. The figures show an increase of the tourism, but our country is near to other developed countries, here we can mention Greece, Croatia and Turkey, where they have a much more developed infrastructure compared to Albania. 
The tourism- is a major component in the economic growth af a country, especially in the coastal areas, a stimuly for a stable development. The internal and the external investments would be very important for this development. A strategy of a good tourism management causes the increase of the investments in the private sector and the economic growth of the country.

During this time the number of the tourists has been continuously growing, by maintaining nearly the same constant number.

The period December- January 2009 compared to the last year period of 2012 there has been of $34 \%$ and compared with the year of 2005 the growth is approximately four times bigger.

Compared to 2008 , in 2009 there are approximately 456 thousand visitors more, who have entered.

Fig 5. The inccomes from the tourism in milion euros

\begin{tabular}{|l|l|l|}
\hline $\mathrm{Nr}$ & Viti & Milionë euro \\
\hline 1 & 2007 & 1,002 \\
\hline 2 & 2008 & 1,170 \\
\hline 3 & 2009 & 1,200 \\
\hline
\end{tabular}

Fig 6. The enters and the exits in the boarders of the foreigners and the Albanians

\begin{tabular}{lrrrr} 
& 2007 & 2008 & 2009 & 2010 \\
\hline Hyrje & & & & \\
Të huaj & $\mathbf{3 , 4 4 4 , 4 1 9}$ & $\mathbf{4 , 0 2 9 , 8 2 0}$ & $\mathbf{4 , 5 1 6 , 3 6 9}$ & $\mathbf{5 , 1 3 5 , 7 9 8}$ \\
Shqiptarë & 937,038 & $1,126,514$ & $1,419,191$ & $1,855,638$ \\
Dalje & $2,507,381$ & $2,903,306$ & $3,097,178$ & $3,280,160$ \\
Të huaj & $\mathbf{3 , 4 5 9 , 4 4 0}$ & $\mathbf{3 , 9 8 8 , 7 7 6}$ & $\mathbf{4 , 4 5 0 , 0 3 5}$ & $\mathbf{5 , 0 5 0 , 8 9 4}$ \\
Shqiptarë & 843,259 & $1,010,043$ & $1,273,555$ & $1,646,534$ \\
\hline & $2,616,181$ & $2,978,733$ & $3,176,480$ & $3,404,360$ \\
\hline
\end{tabular}

It is expected that the number of the foreigners who will enter Albania will be approximately 1.2 million tourist per year, the incomes will be provided by this sector and they will go around 420 million dollars per year, and will be oppened 100 . 000 working positions up to 2015 year.

- The incomes of the tourism in GDP , is calculated in $3.8-4 \%$ or around 45 miliard leke.

- The contribution in the tourism in the Albanian economy is around $11 \%$.

These were the three phases of urbanization in Albania which has passed since the collapse of communism until today.

\section{Conclusions}

- It is unique to Albania from informality to formality transformation. This development of these areas has affected the financial system of our country where restructuring reforms have found economic increasing. It is known that financial stability is a developed system that supports and promotes economic development; also a developed economy cannot do without a developed and sustainable financial sector, in order to resist adverse cyclical developments and external shocks.

- There is still room for improvement of urban management, especially to find a suitable solution to public and private interests in land development and use of property. Urban growth will continue, but the smaller size associated with the increasing rate of urbanization levels similar to other European countries.

- Urbanization is not an autonomous process, but always analyzed with top models in the economic and political development of a country.

\section{References}

Anthony Giddens ' Sociologjia' faqe 531

INSTAT

Vleresim i sektorit urban ne Shqiperi 